\title{
THE INFLUENCE OF USED WHATSAPP GROUP IN ONLINE LEARNING TO STUDENT DISCIPLINE AT ELEMENTARY SCHOOL
}

\author{
Mukhasin $^{1 *}$, Ana Andriani \\ Universitas Muhammadiyah Purwokerto, INDONESIA
}

Received 30 May 2021 - Revised 27 August 2021 • Accepted 19 September 2021

\begin{abstract}
The background of this study is the low attitude of student discipline during distance learning. This study aims to determine the benefits of WhatsApp groups in distance learning on improving the discipline attitude of elementary school students. Student discipline is very important to improve learning outcomes. The data used is secondary data, as well as the research method used is literature study research. The analysis technique used in this study is the content analysis. The data obtained will be collected, analyzed, and concluded to get the expected conclusion. Based on the results of literature research from several journals written by researchers previously showed that the use of WhatsApp groups in distance learning is very useful in the process of increasing student discipline.
\end{abstract}

Keywords: Discipline, students, online learning, elementary school

\section{INTRODUCTION}

Education is one of the investments in the development of human resources as well as a means of increasing skills and ability to navigate life. Educational goals should be educational pressure not only in cognitive aspects or just thinking abilities, but the education process must also prioritize the character, smooth the conscience, so that awareness can be grown about the ability and not the ability of students [1]. Physical and spiritual education must run balanced to get maximum educational results, namely students who have good character.

Character education for elementary school students is very necessary, especially disciplinary characters. The character possessed by someone is basically formed through a fairly long learning process. Human character is not something that has been brought from birth. More than that, characters are formed or even environmental forgiveness and people around the environment. Characters are formed through the learning process in several places, such as at home, school, and in the neighborhood around the residence [2]. Submission of character education must be carried out both in direct learning and in distance learning. In fact, the problems that often arise when learning is the discipline of students. Discipline is an attitude that makes someone able to obey a task or work that is felt according to his responsibilities and in accordance with moral values. Students who have a disciplinary attitude will be able to obey each regulation [3]. The disciplinary attitude owned by students must be applied both in the school environment, family and society.

Discipline is an individual behavior that is able to obey the values and norms that people believe or a group. If associated with the context of this study, it can be concluded that disciplinary attitudes are a condition or behavior where students are able to comply with the applicable regulations in the class [4]. The learning discipline indicator becomes four, namely: a) adherence to school rules, b) compliance with learning activities at school, c) carry out tasks that are their responsibilities, and d) study discipline at home [5].

Students are one of the most important factors in the world of education and for teaching-learning systems. Students are people who come to school to obtain or learn some type of education [6]. But in the fact that students have not fully have discipline in learning. Some of the symptoms of not discipline of students include: late to come to school, not disciplined in uniform, less knowledge a good learning, namely learning before the exam, lazy in doing the tasks that have been given by the teacher, less can learn alone, cannot divide Time to study, there is still coercion to learn from the teacher, often cheating on the results of his friend's work, and doing homework assignments when following other subjects which resulted in the learning process to be disrupted.

Low discipline of students during learning is influenced by several things, among others: 1) the condition of the pandemic that is engulfing the country of Indonesia and the world generally results in restrictions on space for students, 2) less varied learning methods, 3) too many additional tasks, 4) study that done according to daring or where a large part education executants belong teacher and student not yet ready for face condition.

(C) 2021 by the authors; licensee PGSD UMP. This article is an open access article distributed under the terms and conditions of the Creative Commons Attribution License (http://creativecommons.org/licenses/by/4.0/). \mukhasin83@gmail.com ${ }^{1}$, ana.andriani@gmail.com (*Correspondence) 
The progress of science and technology is very influential on the development of the world of education. Changes that occur significantly from learning directly become a long distance learning change the mindset of educators becomes more modern in developing learning. Distance learning or called (PJJ) is the learning carried out without meeting between students and teachers. Online learning is learning that is able to bring together teachers and students in carrying out learning interactions with the assistance of the internet [7]. Online learning is the utilization of the internet network in the learning process. With long distance learning / online both students, teachers and lecturers have time freedom in its implementation. The platforms that can be used in this distance learning include: Google Classroom, Goggle Meet, Zoom, WhatsApp group and others [8].

Grade $\mathrm{V}$ elementary school students most have carried out distance learning. One of the familiar distance learning media and often used is WhatsApp group. WhatsApp (WA) is one of the many communication media favored by all levels of society. The use of WhatsApp has become one of the social media which includes the whole interests of the community in communicating to meet their needs [9], but in the process of learning remotely the use of WhatsApp needs attention from parents and the teachers.

\section{MATERIAL AND METHOD}

The research method used in the study was a literature study of various journals and books. The literature study method is a series of activities relating to the method of collection of libraries, reading and noting, and processing research materials originating from journals or articles that examine the problems related to the problems they want to solve. In the study, there were several differences in the results of the study [10]. Literature or literature studies also mean data collection techniques by reviewing books, literature, notes, and various reports related to the problem that you want to solve [11].

The data used in this research is secondary data. Secondary data is data taken from research conducted by previous researchers, not from direct observers. The method of data collection used in this study is the documentation method. Documentation method is a systematic data collection procedure to review documents both print and electronic [12]. The data analysis technique used in this study is the content analysis method. This analysis is used to obtain valid references and can be re-researched based on the context. In the content analysis, the process of choosing, compare, combine and sort out various sense to find relevant results [13].

\section{RESULT AND DISCUSSION}

Literature study research is a research method by collecting data from various sources that have been carried out by previous researchers. Results Based on research data collected show that from one WhatsApp feature which can be used as a means of online learning is a group chat / WhatsApp group. This media can be made based on the subjects in the school. Through WhatsApp group becomes an online study room, so teachers and students can still take learning [13]. WhatsApp group in learning is the most effective media / tool for learning processes with various situation factors and conditions of students. WhatsApp group is a medium that is easy to use but there are no restrictions so that it is very influential on discipline and student responsibilities [14].

The utilization carried out by classroom teachers in learning activities using the Media WhatsApp group contains the opening, core, and cover activities. Then features that are often used features of photos, videos, documents, WhatsApp group, and Cellphone directly. The menu in WhatsApp is very easy to use by everyone [15].

WhatsApp group is chosen as one of the learning media, because it is viewed in terms of the number of users, functions and methods of use, where educators can share the subject matter or tasks in the form of images, PDF, PPT, DOC, XLS, audio, Video directly and Request response (answer) from group participants (students). WhatsApp is also a good application for smartphone based learning, such as to complete tasks from educators. In connection with the settlement of cellular application tasks such as WhatsApp is preferred than discussion in class. Because through the group, whatever posted by educators or students will be directly accessible to group participants who are online. That is, learning activities using WhatsApp Group applications bring benefits for the achievements and attitudes of students on learning and education on mobile [16].

WhatsApp Group provides a lot of advantages, including: a) not wasteful quota like other applications. b) Facilitate learning during Covid-19 pandemic. c) Through WhatsApp group, the material delivered by the teacher can be accessed by all students. d) Can make discussions about subject matter [13]. e) Learning can be easily accessed through smartphones or other devices and flexible learning time can be done with opportunities anytime, f) extensive insight with conventional methods due to using a variety of accesses and given a lot of time opportunities in accessing knowledge [14]. 
The problem in using WhatsApp group is: a) a weak network makes it difficult to download the material delivered by the teacher. b) The number of entrances, resulting in slow cellphones. c) If the individual evaluation test is sent through a group, students who have not finished can see the results of their friends [13]. d) It is difficult to control students who seriously take lessons and those who do not, e) more theoretical learning compared to practices [14].

The solution taken to overcome the shortcomings of WhatsApp group is a) Master maximizes using existing media, namely with voice notes in WhatsApp and provide handouts so that students can study the material independently, b) the teacher uses a varied learning media to attract students to learn , c) The teacher can implement small group learning with a maximum of 3 people, so that students can share knowledge, d) Teachers can provide direct directives to students through personal WhatsApp if there are difficulties [14].

\section{CONCLUSION}

Based on library studies and the results of the study of literature studies it can be concluded that the use of what Groups in distance learning is very helpful in increasing student discipline. Media WhatsApp provides various features that make it easier for students to implement the learning process. The advantage of using WhatsApp groups in learning is cheap, accessible, more flexible, and easy to use time. Constraints in using WhatsApp groups include a weak internal network, Headphone memory is full fast, the teacher is difficult to control the students, and boring learning. Some ways to overcome the problem in the use of WhatsApp groups include: teachers maximize existing features, form small groups, and provide direct direction. Researchers hope this research can be useful as an alternative review for readers and further researchers relating to the use of social media in the learning process.

\section{REFERENCES}

[1] Suyatno. 2004. Teknik Pembelajaran Bahasa dan Sastra. Surabaya: SIC.

[2] Andriani, A., \& Wakhudin, W. (2020). Implementasi Pendidikan Karakter Melalui Model Pembelajaran Discovery Learning Di Mim Pasir Lor Karanglewas Banyumas. Jurnal Pengabdian Masyarakat, 1(2), 51-63. Dari https://scholar.google.com/scholar?oi=bibs\&hl=id\&q=related:GRZhPL4HniEJ:scholar.google.com/

[3] Jauhary, H. (2019). Hidup sukses dengan disiplin. Semarang, Indonesia: Mutiara Aksara.

[4] Pancarani, D. P. (2019). Peran guru dalam membentuk sikap disiplin siswa kelas I Sekolah Dasar melalui penghargaan dan konsekuensi (Doctoral dissertation, Universitas Pelita Harapan). Dari http://repository.uph.edu/5149/

[5] Daryanto. 2013. Strategi dan Tahap Mengajar. Bandung : CV Yrama Widya.

[6] Safitri, C. (2019). Hubungan Antara Dukungan Sosial dengan Motivasi Berprestasi pada Siswa Kelas XI Madrasah Aliyah Al Wasliyah 12 Perbaungan (Doctoral dissertation, Universitas Medan Area). Dari http:/ / repository.uma.ac.id/bitstream/123456789/10915/1/158600026\%20-\%20Chairunnisa \%20Safitri\%20\%20Fulltext.pdf

[7] Kuntarto, E. 2017. “Keefektifan Model Pembelajaran Daring dalam Perkuliahan Bahasa Indonesia di Perguruan Tinggi". Journal Indonesian Language Education and Literature. 3, (1), 99-110.

[8] Magdalena, I., Mauludyana, B. G., \& Gusmawati, L. (2020). Efektivitas Pembelajaran Daring Menggunakan Media Online Selama Pandemi Covid-19 di SDN Curug Kulon 1. BINTANG, 2(2), 326-335. Dari https:/ / ejournal.stitpn.ac.id/index.php/bintang/article/view/1056/740

[9] Yensy, N. A. (2020). Efektifitas Pembelajaran Statistika Matematika melalui Media Whatsapp Group Ditinjau dari Hasil Belajar Mahasiswa (Masa Pandemik Covid 19). Jurnal Pendidikan Matematika Raflesia, 5(2), 65-74. Dari https://ejournal.unib.ac.id/index.php/jpmr/article/view/11410/5736

[10] Salsabila, U. H., Utami, S. N., Zahra, A., Haikal, F., \& Cahyono, A. (2021). Pengaruh Penggunaan Media Belajar Online Selama Pandemi. Jurnal Ilmiah Wahana Pendidikan, 7(1), 1-9. Dari http://jurnal.unibrah.ac.id/index.php/JIWP/article/view/570/384

[11] MIRZAQON T, A. B. D. I. (2017). Studi Kepustakaan Mengenai Landasan Teori dan Praktik Konseling Expressive Writing. Jurnal BK Unesa, 8(1). Dari https://jurnalmahasiswa.unesa.ac.id/index.php/jurnal-bkunesa/article/view/22037/20201

[12] Bowen, G. A. (2009). Document Analysis as a Qualitative Research Method. Qualitative research journal. Dari https://www.emerald.com/insight/content/doi/10.3316/QRJ0902027/full/html

[13] Saragih, E. M., \& Ansi, R. Y. (2020, October). Efektivitas penggunaan whatsapp group selama pandemi covid19 bagi pelaku pendidik. In Seminar Nasional Multi Disiplin Ilmu Universitas Asahan. Dari http://www.jurnal.una.ac.id/index.php/semnasmudi/article/view/1527

[14] Bensulong, A., Afifah, F. N., \& Solikhah, I. Z. (2021). Penggunaan Whatsapp dan Google Form dalam Pembelajaran Bahasa Indonesia Di SMK N 2 Sewon Bantul. Lingua Rima: Jurnal Pendidikan Bahasa dan Sastra Indonesia, 10(1), 85-90. Dari http://jurnal.umt.ac.id/index.php/lgrm/article/view/4093/2310 
[15] Lestari, W., Arsil, A., \& Noviyanti, S. (2021). Pemanfaatan Whatsapp Sebagai Media Pembelajaran Dalam Jaringan Masa Pandemi Covid-19 Di Kelas Vi Sekolah Dasar (Doctoral dissertation, Universitas Jambi). Dari https://repository.unja.ac.id/15971/

[16] Pustikayasa, I. M. (2019). Grup WhatsApp Sebagai Media Pembelajaran. Widya Genitri: Jurnal Ilmiah Pendidikan, Agama Dan Kebudayaan Hindu, 10(2), 53-62. Dari http://jurnal.stahds.ac.id/widyagenitri/article/view/281/141

\section{http://jurnalnasional.ump/index.php/dinamika}

